\title{
PHARMACOGNOSTIC AND PHYTOCHEMICAL INVESTIGATION OF AILANTHUS EXCELSA ROXB. BARK
}

\section{RASIKA D BHALKE, MAHENDRA A GIRI*}

Department of Pharmacognosy, Sanjivani College of Pharmaceutical Education and Research, Kopargaon, Maharashtra, India. Email: mahijaan.mahendra@gmail.com

Received: 19 November 2019, Revised and Accepted: 10 January 2020

\section{ABSTRACT}

Objective: The present investigation aims at detail pharmacognostic study of the bark of Ailanthus excelsa Roxb. (BAE). A. excelsa is an important plant in Indian system of medicine belonging to the family Simaroubaceae.

Methods: BAE was studied for various pharmacognostic evaluation parameters such as examination of morphological and microscopic characters and physicochemical evaluation. The total phenolic content was determined using Folin-Ciocalteu reagent spectrophotometrically and calculated as gallic acid equivalent (GAE/g).

Results: The morphological studies revealed that BAE is yellowish-brown in color with a smooth texture and characteristic odor. Microscopical studies indicated the presence of cork, cortex with a group of stone cells in BAE with secondary phloem region. Prismatic and acicular raphides calcium oxalate crystals were observed. The total ash value of BAE was found to be $8.95 \%$. Bark powder was successively extracted in Soxhlet extractor using solvents from low polarity to high polarity such as petroleum ether, chloroform, ethyl acetate, and methanol. Alkaloids, glycosides, tannins, triterpenoids, carbohydrates, and flavonoids are present when the preliminary phytochemical investigation was done. The total phenolic content in BAE was found to be $9.95 \mathrm{mg} \mathrm{GAE} / \mathrm{g}$.

Conclusion: The results obtained from the study provide information for proper identification and standardization of plant.

Keywords: Pharmacognostic study, Phytochemical investigation, Ailanthus excelsa Roxb.

(C) 2020 The Authors. Published by Innovare Academic Sciences Pvt Ltd. This is an open access article under the CC BY license (http://creativecommons. org/licenses/by/4. 0/) DOI: http://dx.doi.org/10.22159/ajpcr.2020.v13i3.36409

\section{INTRODUCTION}

Tree Ailanthus excelsa Roxb. is indigenous to Central and Southern India commonly known as a plant of heaven and is belong to the family Simaroubaceae. Quassinoids are present in various plants of Simaroubaceae family, which are highly oxygenated triterpenes and are having a bitter taste. Quassinoids have shown as an antitumor, antiviral, anti-inflammatory, antiamebic, antimalarial, insecticidal, antitubercular, anticancer, amebicidal, antiulcer, herbicidal, antifeedant, etc. [1-4].

Quassinoids such as excelsin, glaucarubine, ailanthinone, glaucarubinone, and glaucarubolone are present in stem bark. Leaves contain flavonoids such as kaempferol, luteolin, and apigenin while fruits contain quercetin [5-8]. The bark is used as bitter, astringent, anthelmintic, febrifuge, appetizer, bitter tonic, and taste bud stimulant. It is also used in the treatment of various disorders of gastrointestinal tract and respiratory tract. It is used as blood purifier in skin diseases [9]. Authenticity, purity, and assay of crude drug must be crosschecked for standardization and quality assurance. Hence, the aim of the present study is to evaluate various pharmacognostic parameters of $A$. excelsa Roxb. bark. In the present study, we have evaluated macroscopy, microscopy, physicochemical, and phytochemical parameters of bark of A. excelsa (BAE)

\section{METHODS}

\section{Plant material}

Fresh bark of A. excelsa Roxb. was collected in the month of June from the local region of Shirdi, Maharashtra, India, and authenticated from the Botanical Survey of India. A voucher specimen no AER01 is maintained. For the macroscopic and microscopic study, fresh bark was used and for physicochemical characterization, dried bark powder was used.

\section{Macroscopic and organoleptic studies}

Identification of plant material and its standardization is easy with macroscopic study. The fresh root bark and stem bark were subjected to macroscopic studies such as color, odor, appearance, taste, and texture organoleptic characters.

\section{Microscopic studies}

Bark microscopy

Microscopical studies were performed on the fresh bark of A. excelsa. Microscopic sections were taken by freehand sectioning using microtome cutter. A number of temporary and permanent sections of the microscopical sections of the bark were prepared and examined microscopically under MOTIC IMAGES PLUS 2.0 software. Identification tests for lignified tissues, starch, alkaloids, mucilage, calcium oxalate crystals, and phenolic compounds were performed using stains such as hydrochloric acid - phloroglucinol, weak iodine solution, Dragendorff's reagent, ruthenium red, $60 \% \mathrm{H}_{2} \mathrm{SO}_{4}$, and ferric chloride, respectively [10].

\section{Powder microscopy}

The powder is prepared by grinding dried bark and passed through sieve No. 60 which is used to study the presence or absence of various types of tissues in bark $[11,12]$.

\section{Physicochemical parameters}

Ash value, extractive values, and fluorescence analysis were determined according to the official methods and as per the WHO guidelines on quality control methods for medicinal plant materials [13-20].

\section{Determination of ash values}

About $5 \mathrm{~g}$ of powder was used for determining the ash content of the drug. The powder is spread in a pre-ignited and weighed silica crucible. 
Then, the crucible was incinerated gradually to complete incineration. After cooling, the crucible was weighed to get the total ash content and then the ash was subjected for determining the acid-insoluble and water-soluble ash. The percentage of total ash was calculated.

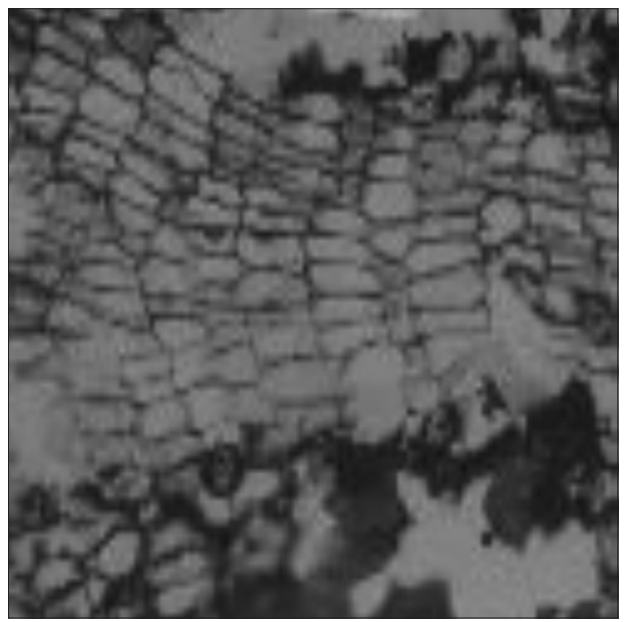

Fig. 1: Cork cells

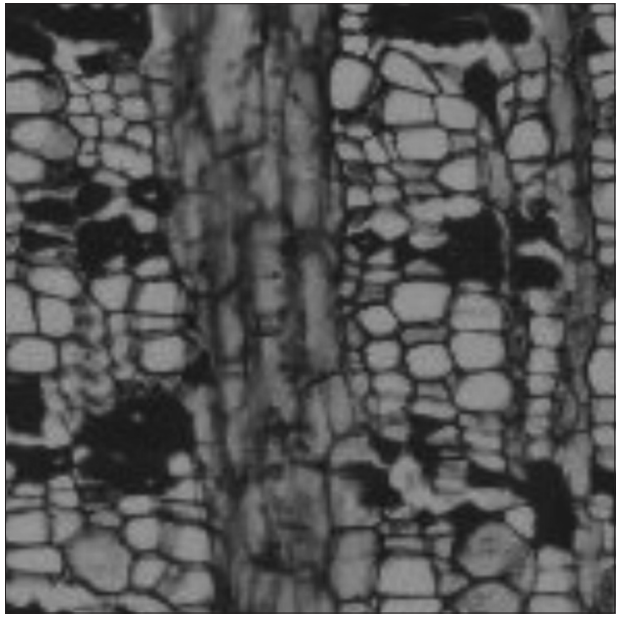

Fig. 2: Phloem region showing phloem fibers, phloem parenchyma, and medullary rays

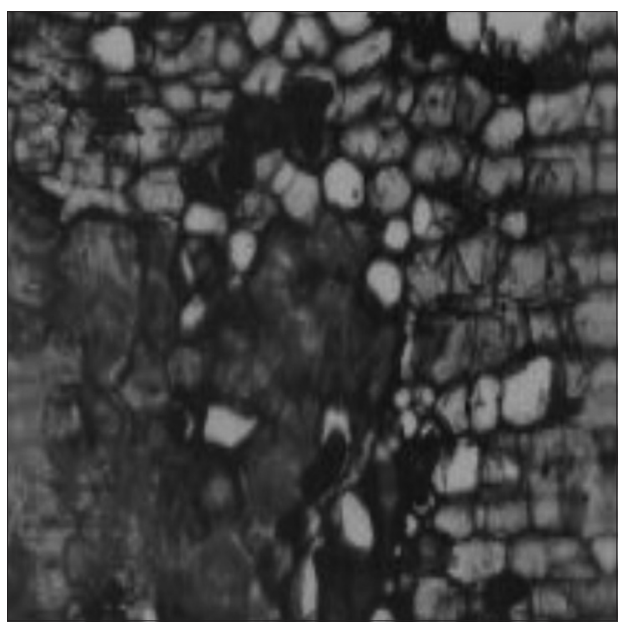

Fig. 3: Sclerenchyma in the phloem region
Determination of extractive values

Solvents with different polarities such as petroleum ether, chloroform, ethyl acetate, and methanol were used for the determination of extractive values as there is diversity in the chemical nature of the

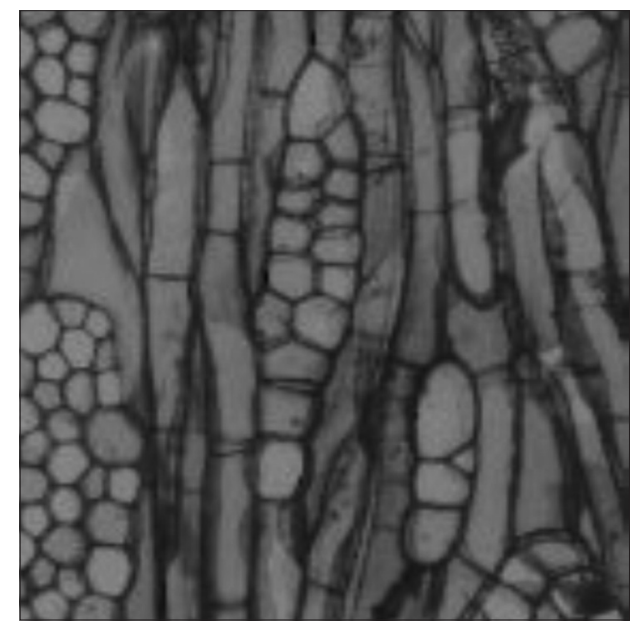

Fig. 4: Multiseriate medullary rays

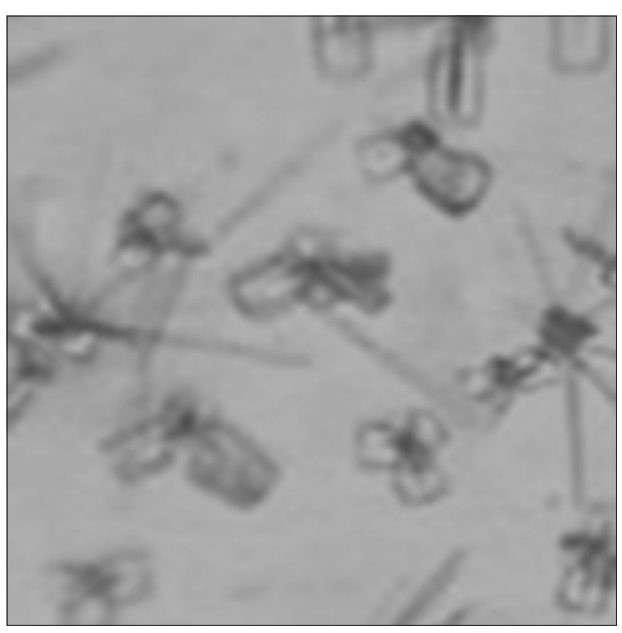

Fig. 5: Calcium oxalate crystals

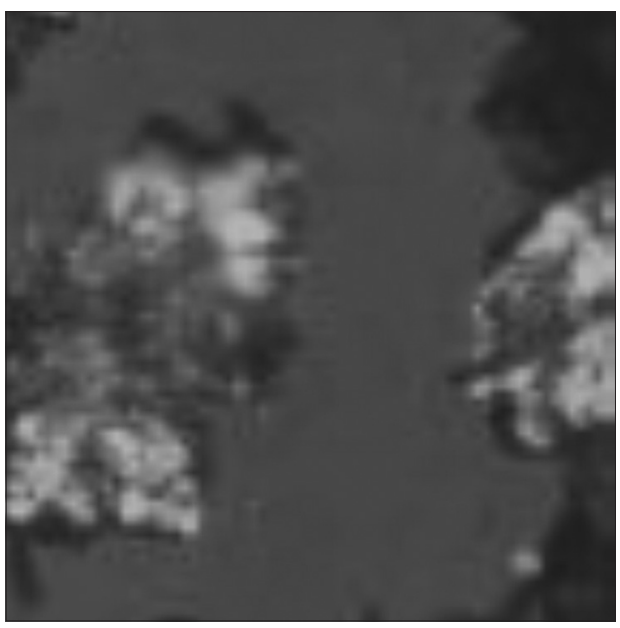

Fig. 6: Stone cells 
various phytoconstituents. About 5 g of powdered material was subjected to continuous Soxhlet extraction with $100 \mathrm{ml}$ of petroleum ether, chloroform, ethyl acetate, and methanol as solvents. The determination of extractive values gives idea about qualitative and quantitative perspective of chemical constituents. After complete

Table 1: Physicochemical parameters of the bark of Ailanthus excelsa

\begin{tabular}{lll}
\hline S. No. & Physicochemical parameters & $\mathbf{\%} \mathbf{w} / \mathbf{w}($ Mean \pm SD $)$ \\
\hline 1. & Total ash & $8.95 \pm 0.45$ \\
2. & Acid-insoluble ash & $3.5 \pm 0.75$ \\
3. & Water-soluble ash & $4.62 \pm 0.34$ \\
4. & Sulfated ash & $1.23 \pm 0.62$ \\
5. & Foreign organic matter & $1.01 \pm 0.59$ \\
\hline
\end{tabular}

Table 2: Fluorescence analysis of different extracts and powder of BAE with various reagents

\begin{tabular}{|c|c|c|c|}
\hline \multirow{2}{*}{$\begin{array}{l}\text { Extract/ } \\
\text { powder }\end{array}$} & \multicolumn{3}{|l|}{ Color in } \\
\hline & Daylight & $\begin{array}{l}\text { Short UV } \\
(254 \mathrm{~nm})\end{array}$ & $\begin{array}{l}\text { Long UV } \\
(365 \mathrm{~nm})\end{array}$ \\
\hline $\begin{array}{l}\text { Petroleum ether } \\
\text { extract }\end{array}$ & Light green & Green & Dark green \\
\hline $\begin{array}{l}\text { Chloroform } \\
\text { extract }\end{array}$ & Pale brown & Dark brown & Greenish-brown \\
\hline $\begin{array}{l}\text { Ethyl acetate } \\
\text { extract }\end{array}$ & Brown & Yellowish-brown & Greenish-brown \\
\hline $\begin{array}{l}\text { Methanol } \\
\text { extract }\end{array}$ & Greenish-black & Black & Black \\
\hline Powder & Brown & Brown & Brown \\
\hline $\begin{array}{l}\text { Powder+sodium } \\
\text { hydroxide in } \\
\text { methanol }\end{array}$ & Greenish-black & Greenish-black & Greenish-black \\
\hline $\begin{array}{l}\text { Powder+sodium } \\
\text { hydroxide in } \\
\text { water }\end{array}$ & Dark brown & Brown & Dark brown \\
\hline $\begin{array}{l}\text { Powder+1 N } \\
\text { hydrochloric acid }\end{array}$ & Dark brown & $\begin{array}{l}\text { Fluorescent } \\
\text { green }\end{array}$ & Dark brown \\
\hline
\end{tabular}

BAE: Bark of Ailanthus excels, UV: Ultraviolet

Table 3: Extractive values of the bark of Ailanthus excels

\begin{tabular}{lll}
\hline S. No. & Type of solvent & $\begin{array}{l}\text { \% extractive value } \\
\text { mean } \pm \text { standard deviation }\end{array}$ \\
\hline 1. & Petroleum ether $(60-40)$ & $1.2 \pm 0.54$ \\
2. & Chloroform & $0.9 \pm 0.19$ \\
3. & Ethyl acetate & $1.5 \pm 1.62$ \\
4. & Methanol & $2.3 \pm 1.26$ \\
\hline
\end{tabular}

extraction, the extracts are concentrated in a rotary vacuum evaporator and dried in a vacuum desiccator. Then, the extractive values are calculated as percentage $\mathrm{w} / \mathrm{w}$ of solvent-soluble extractive.

\section{Determination of moisture content}

Moisture content is determined using the loss of weight on drying method. For this, $5 \mathrm{~g}$ of powdered drug was taken and kept in an oven at $105^{\circ} \mathrm{C}$ until a constant weight was obtained. The amount of moisture present in the sample was calculated as a reference to the air-dried material.

Fluorescence analysis

When exposed to ultraviolet radiation, crude drugs show their own characteristic fluorescence which is dependent on chemical constituents present in it. This analysis is useful to identify adulteration or substitution in the crude drug. In the present study, fluorescent analysis of powder as such and after treatment with different reagents is done.

\section{Preliminary phytochemical analysis}

The identification of phytoconstituents is done with the help of systematic preliminary phytochemical screening. It is also helpful in establishing a chemical profile of a crude drug for its proper evaluation. Extracts obtained by continuous Soxhlet extractor using solvents with different polarities such as petroleum ether, chloroform, ethyl acetate, and methanol were subjected to standard preliminary phytochemical tests for the identification of the presence of chemical constituents such as alkaloids, glycosides, tannins, flavonoids, sterols, fats, oils, phenols, and saponins.

\section{Estimation of total phenol}

Ten milligrams of standard gallic acid were dissolved in $100 \mathrm{ml}$ distilled water in a volumetric flask and used as a stalk solution. From this stalk solution, $0.5-2.5 \mathrm{ml}$ of aliquots were pipetted out, in which $10 \mathrm{ml}$ distilled water and $1.5 \mathrm{ml}$ Folin-Ciocalteu reagent were added. After $5 \mathrm{~min}, 4 \mathrm{ml}$ of $20 \%$ sodium carbonate solution was added followed by volume adjustment up to $25 \mathrm{ml}$ with distilled water. This mixture is incubated at room temperature for $30 \mathrm{~min}$. The absorbance of the solution was recorded at $765 \mathrm{~nm}$ and a standard curve of absorbance versus concentration of gallic acid was plotted. One gram of the powdered drug of BAE was extracted with $70 \%$ methanol $(15 \times 3$ times $)$, filtered, and pooled and the volume was adjusted to $50 \mathrm{ml}$ with $70 \%$ methanol in a volumetric flask. In $5 \mathrm{ml}$ of extract, $10 \mathrm{ml}$ of water and $1.5 \mathrm{ml}$ of Folin-Ciocalteu reagent were added and were kept for $5 \mathrm{~min}$ and then $4 \mathrm{ml}$ of $20 \%$ sodium carbonate solution followed by the addition of distilled water to adjust volume up to $25 \mathrm{ml}$. The mixtures were incubated at room temperature for $30 \mathrm{~min}$ and the absorbance was recorded at $765 \mathrm{~nm}$ in a spectrophotometer. The percentage of total phenolics was calculated from the calibration curve of gallic acid and total phenolics were expressed as milligrams of gallic acid equivalent (GAE) per gram of dry weight (mg GAE/g dw) [21-23].

Table 4: Preliminary phytochemical analysis of various extracts of bark

\begin{tabular}{|c|c|c|c|c|}
\hline Type of constituent & Petroleum ether & Chloroform & Ethyl acetate & Methanol \\
\hline Alkaloids & - & + & - & - \\
\hline Glycosides & - & - & - & + \\
\hline Carbohydrate & - & - & - & + \\
\hline Reducing sugars & - & - & - & + \\
\hline Flavonoids & - & - & + & - \\
\hline Tannins and phenolic & - & - & - & + \\
\hline Protein and amino acids & - & - & - & - \\
\hline Triterpenoids & + & - & - & - \\
\hline Saponins & - & - & - & + \\
\hline Steroids and sterols & + & - & - & + \\
\hline
\end{tabular}




\section{RESULTS AND DISCUSSION}

\section{Macroscopic and organoleptic characters}

The morphological studies revealed that BAE is grayish-brown externally and yellowish-brown in color internally with a smooth texture. The bark is hard, fibrous in the inner part, and granular in the outer part. The outer and inner barks do not separate easily. BAE shows longitudinal wrinkles with small transverse cracks. The fresh bark emits an agreeable odor, the taste is slightly bitter.

\section{Microscopic studies}

Bark microscopy

Microscopy

a. Transverse section of the bark

The transverse section of the bark shows the following microscopic characteristics:

Cork: The cork region was found to be well defined in phellem, phellogen, and phelloderm. Cork cells are rectangular, as shown in Fig. 1 and in 12-15 layers. Some of the cork cells are with brownish matter.

Cortex: Cells of cortex region are loosely arranged. Simple prismatic as well as rosette type of calcium oxalate crystals with average size of $15 \mu \mathrm{m}$ in width and $18 \mu \mathrm{m}$ are present in cortex region. Groups of stone cells are observed, as shown in Fig. 1.

Phloem region: Funnel-shaped medullary rays are found, which are uniseriate to multiseriate. It shows the presence of lignified phloem fibers in a group of 5-10 fibers surrounded by phloem parenchyma (Fig. 2). The phloem region shows a trace of calcium oxalate crystals (Figs. 3 and 4).

b. Powder characteristics

\section{Microscopical examination of the powder}

Calcium oxalate crystals

Simple prismatic and rosette type of calcium oxalate crystals with an average width of $10 \mu \mathrm{m}$ and length of $15 \mu \mathrm{m}$ were found (Fig. 5).

Stone cells: Thick-walled lignified stone cells were observed with an average size of 70-85 $\mu \mathrm{m} \times 25-30 \mu \mathrm{m}$, as shown in Fig. 6 .

\section{Physicochemical investigation}

In the identification of crude drug, adulteration, substitution, and physicochemical parameters play a very important role and also useful in the setting of proper standards. Various physicochemical parameters such as ash values, extractive values, moisture content, and fluorescence analysis on reaction with various chemical reagents were investigated and the results are presented in Tables 1 and 2. Ash values are an important parameter in the identification of earthy matter or inorganic composition and other impurities present along with the drug. The extractive values are primarily useful for the determination of the exhausted or adulterated drug and results are given in Table 3.

\section{Preliminary phytochemical screening}

Preliminary phytochemical screening mainly revealed the presence of steroids and triterpenes in petroleum ether extract; alkaloids in chloroform extract; flavonoids in ethyl acetate extracts; and carbohydrate, reducing sugars, tannin, and glycoside in methanol extract (Table 4).

\section{Estimation of total phenol}

Linearity curve of gallic acid, the curve absorbance versus concentration, is described by the equation $y=0.912 x+0.0168\left(R^{2}=0.998\right)$, here, $y=a b s o r b a n c e$ and $x=$ concentration. The amount of total phenolics was found to be $9.95 \mathrm{mg} \mathrm{GAE} / \mathrm{g}$ of dry material in BAE.

The quantitative determinations, such as total phenol content, are useful for setting standards for crude drugs. The physical constant evaluation is a useful parameter in detecting adulteration or improper handling of the drug. Various ash values are important to determine the purity of the drug, i.e., the presence or absence of foreign inorganic matter. Since the plant $A$. excelsa is useful in the traditional medicine for the treatment of some ailment, it is important to standardize it for use as a drug. The pharmacognostic constants such as diagnostic microscopic features, powder characteristics, and the physicochemical evaluation with numerical standards reported in this work could be useful for the compilation of a suitable monograph for its proper identification $[24,25]$.

\section{CONCLUSION}

The results obtained from the study provide information for proper identification of plant. Adulteration or substitution can be easily identified by comparing with these results.

\section{ACKNOWLEDGMENT}

The authors wish to express their sincere thanks to the management of Sanjivani College of Pharmaceutical Education and Research, Kopargaon, for providing research facilities for completion of project work.

\section{AUTHORS' CONTRIBUTIONS}

Both authors contributed equally to this manuscript.

\section{CONFLICTS OF INTEREST}

Declared none.

\section{AUTHORS' FUNDING}

Sanjivani College of Pharmaceutical Education and Research, Kopargaon.

\section{REFERENCES}

1. Anonymous. The Wealth of India, Raw Materials. New Delhi: Publication and Information Directorate; 1985. p. 116-8.

2. Chopra RN, Chopra IC, Handa KL, Kapur LD. Chopras Indigenous Drugs of India. $2^{\text {nd }}$ ed. Kolkata: United Nations, Dharand Sons Private Ltd.; 1958. p. 408.

3. Central Council for Research in Ayurveda and Siddha. Database, Medicinal Plants Used In Ayurveda. New Delhi, India: Central Council for Research in Ayurveda and Siddha; 2000. p. 50-9.

4. Kirtikar KR, Basu BD. Indian Medicinal Plants. Vol. 1. Dehradun, India: International Book Distributors; 1995. p. 371-2.

5. Khan SA, Shamsuddin KM. Quassinoids from Ailanthus excelsa. Indian J Chem 1978;16B:1045-6.

6. Khan SA, Shamsuddin KM. Isolation and structure of 13 18-dehydroexcelsin, a quassinoid and glaucarubol from Ailanthus excelsa. Phytochemistry 1980;19:2484-5.

7. Khan SA, Zuberi SS. Isolation and structure of excelsin a new quassinoid from Ailanthus excelsa. Indian J Chem 1980;19B:183-184.

8. Mondal AK, Mandal S. Biochemical and clinical studies of Ailanthus excelsa Roxb. Pollen with reference to its dispersal. Bangladesh J Bot 1997;26:115-20

9. Kumar D, Bhat ZA, Singh P, Shah MY, Bhujbal SS. Ailanthus excelsa Roxb. Is really a plant of heaven. Int J Pharmacol 2010;6:535-50

10. Brain KR, Turner TD. The Practical Evaluation of Phytopharmaceuticals. Bristol: Wright-Scientechnica; 1975. p. 4-9.

11. Kokate CK. Practical Pharmacognosy. $1^{\text {st }}$ ed. New Delhi: Vallabh Prakashan; 1994. p. 15-30.

12. Khandelwal KR. Practical Pharmacognosy. $18^{\text {th }}$ ed. Pune: Nirali Publication; 2007. p. 10-4.

13. Government of India. Indian Pharmacopeia. $4^{\text {th }}$ ed. New Delhi: Ministry of Health and Welfare, Controller of Publications; 1996. p. A53-4.

14. Government of India. The Ayurvedic Pharmacopoeia of India. $1^{\text {st }}$ ed. New Delhi: Ministry of Health and Family Welfare, Department of Indian Systems of Medicines and Homeopathy; 1996. p. A53-5.

15. World Health Organization. Quality Control for Medicinal Plant Material. New Delhi: AITBS Publishers; 1998. p. 46-7.

16. World Health Organization. Quality Control for Medicinal Plant Material. Geneva: World Health Organization; 1992. p. 22-34 
17. Rabinarayan A, Switu J, Harisha CR, Vinay S. Pharmacognostical and phytochemical analysis on leaves of Homalium ceylanicum (Gardn.) Benth. Pharmacogn J 2018;10:272-5.

18. Tang GQ, Lin XJ, Lai XD, Gong X, Ji SG. Pharmacognostic studies of Psychotria rubra (Lour.) Poir. Pharmacogn J 2018;10:249-5.

19. Roy P, Mandal P, Panda S, Mitra S, Subba A. Pharmacognosy and phytochemical screening of some plant derived medicine to treat dysmenorrheal pain by the Rajbanshi community. Pharmacogn $\mathrm{J}$ 2018;10:738-46

20. Mandal AK, Shakila R, Divya KG, Rubeena M, Kumar KN, Sathiyarajeswaran P. Pharmacognostical-physicochemical evaluation and development of HPTLC finger print for Cichorium intybus L. Fruits. Pharmacogn J 2018;10:694-9.

21. Bhalke RD, Pal SC. Pharmacognostic and preliminary phytochemical investigations on Pterospermum acerifolium wood. Int J Pharm Bio Sci 2012;3:1-8.

22. Singleton VL, Orthofer R, Lamuela-Raventos RM. Analysis of total phenols and other oxidation substrates and antioxidants by means of folin-ciocalteu reagent. Methods Enzymol 1999;299:152-78.

23. Sembiring EN, Elya B, Sauriasari R. Phytochemical screening, total flavonoid and total phenolic content, and antioxidant activity of different parts of Caesalpinia bonduc (L.) Roxb. Pharmacogn J 2018;10:123-7.

24. Gogoi N, Bhuyan B, Deka T. Pharmacognostic standardization preliminary phytochemical screening and TLC fingerprinting of the bark of Cascabela thevetia. Int J Pharm Pharm Sci 2019;11:125-130.

25. Naik R, Harisha CR, Acharya R. A comparative pharmacognostical evaluation of three botanical source plants of Jivanti. Int J Pharm Pharm Sci 2018;10:61-6. 